\title{
Angiotensin II enhances noradrenaline release from sympathetic nerves of the rat prostate via a novel angiotensin receptor: implications for the pathophysiology of benign prostatic hyperplasia
}

\author{
M E Fabiani ${ }^{1}$, M Sourial ${ }^{1}$, W G Thomas ${ }^{3}$, C I Johnston ${ }^{1,3}$ \\ and A G Frauman ${ }^{2}$ \\ ${ }^{1}$ Department of Medicine, University of Melbourne, Austin \& Repatriation Medical Centre, Heidelberg VIC 3084, Australia \\ ${ }^{2}$ Clinical Pharmacology \& Therapeutics Unit, Department of Medicine, University of Melbourne, Austin \& Repatriation Medical Centre, Heidelberg VIC 3084, \\ Australia \\ ${ }^{3}$ Baker Medical Research Institute, St Kilda Road Central, Melbourne VIC 8008, Australia \\ (Requests for offprints should be addressed to M E Fabiani, Department of Medicine, University of Melbourne, Austin \& Repatriation Medical Centre, \\ Heidelberg VIC 3084, Australia; Email: m.fabiani@austin.unimelb.edu.au)
}

\begin{abstract}
The renin-angiotensin system (RAS) is present in the human prostate and may be activated in benign prostatic hyperplasia $(\mathrm{BPH})$, possibly contributing to the pathophysiology of this disorder by enhancing local sympathetic tone and cell growth. The functional role of the RAS in the prostate, however, is unknown. The present study was undertaken to determine whether angiotensin (Ang) II enhances sympathetic transmission in the prostate. The neuronal stores of the rat prostate were labelled with $\left[{ }^{3} \mathrm{H}\right]$ noradrenaline (NA). Ang II and Ang I enhanced $\left[{ }^{3} \mathrm{H}\right] \mathrm{NA}$ release in a concentration-dependent manner. The Ang II receptor subtype 1 ( $\mathrm{AT}_{1}$ receptor) antagonist losartan and the $\mathrm{AT}_{2}$ receptor antagonist PD123319 inhibited this facilitatory effect of Ang II and Ang I, whereas the other $\mathrm{AT}_{2}$ receptor antagonist, CGP42112, was without effect. Bradykinin also increased $\left[{ }^{3} \mathrm{H}\right] \mathrm{NA}$ release, which was inhibited by the $B_{2}$ receptor antagonist
\end{abstract}

Hoe140. The angiotensin-converting enzyme inhibitor captopril inhibited the effect of Ang I, but potentiated that of bradykinin. Interestingly, captopril alone produced an increase in $\left[{ }^{3} \mathrm{H}\right] \mathrm{NA}$ release which was inhibited by Hoe140. Losartan, but not PD123319 or CGP42112, inhibited $\left[{ }^{125} \mathrm{I}\right]$-Ang II binding in Chinese hamster ovary cells transfected with the $\mathrm{AT}_{1 \mathrm{a}}$ or $\mathrm{AT}_{1 \mathrm{~b}}$ receptor. In contrast, in cells expressing the $\mathrm{AT}_{2}$ receptor, PD123319 and CGP42112, but not losartan, inhibited $\left[{ }^{125} \mathrm{I}\right]$-Ang II binding. In conclusion, Ang II enhances the release of NA from sympathetic nerves of the rat prostate via a novel functional receptor distinct from the cloned $\mathrm{AT}_{1 \mathrm{a}}, \mathrm{AT}_{1 \mathrm{~b}}$ or $\mathrm{AT}_{2}$. These data provide direct evidence in support of a functional role for the local RAS in modulating sympathetic transmission in the prostate, which may have important implications for the pathophysiology of $\mathrm{BPH}$.

Journal of Endocrinology (2001) 171, 97-108

\section{Introduction}

Benign prostatic hyperplasia/hypertrophy $(\mathrm{BPH})$ is a highly prevalent disorder that represents the most common cause of urinary obstruction in the ageing male population and frequently co-exists with hypertension (Garraway et al. 1991, Maruenda et al. 1999). BPH is characterised by increased cellular proliferation of stromal elements and enhanced sympathetic smooth muscle tone (Isaacs \& Coffey 1989, McNeal 1990, Madsen \& Bruskewitz 1995). In patients with $\mathrm{BPH}$, approximately $50 \%$ of total urethral pressure is due to increased sympathetic smooth muscle tone, which can be ameliorated by $\alpha_{1}$-adrenoceptor blockers such as prazosin, terazosin or doxazosin (Furuya et al. 1982, Kirby 1989, Madsen \& Bruskewitz 1995). The prostate is innervated by sympathetic nerves which, upon stimulation, release the chemical transmitter noradrenaline
(NA) and evoke smooth muscle contraction, mediated by $\alpha_{1}$-adrenoceptors of the $\alpha_{1 \mathrm{~A}}\left(\alpha_{1 \mathrm{c}}\right)$ subtype (Forray et al. 1994, Marshall et al. 1995). Moreover, there is some evidence to suggest that local sympathetic activity may also influence prostate growth (McVary et al. 1994). For example, it has been reported that unilateral sympathectomy of the lower urinary tract reduces ventral prostate weight in rats (McVary et al. 1994). Thus enhanced sympathetic activity is a major factor in the development of $\mathrm{BPH}$, influencing smooth muscle tone and, possibly, growth of the prostate.

The renin-angiotensin system (RAS) is a hormonal cascade that has an important role in regulating blood pressure and cardiovascular homeostasis (Peach 1977, Johnston 1990). Similarly, hyperactivity of the RAS has been implicated in the development of hypertension and other cardiovascular disorders (Nicholls et al. 1998). 
Angiotensin II (Ang II) is the principal effector peptide of the RAS and is formed by the sequential cleavage of the precursor macromolecule, angiotensinogen, to the inactive decapeptide Ang I by renin, and then hydrolysed to the active octapeptide Ang II by angiotensin-converting enzyme (ACE) (Johnston 1990). It should be noted, however, that ACE is not a specific enzyme and can degrade bradykinin and a host of other peptides to inactive fragments (Fabiani et al. 2000). In addition to its formation within the circulation, Ang II can also be generated locally in many target tissues such as the kidney, heart, brain and blood vessels, and may therefore also mediate autocrine or paracrine effects (Campbell 1987, Dzau 1988, Johnston 1992).

The effects of Ang II are subserved by at least two distinct receptor subtypes, denoted $\mathrm{AT}_{1}$ and $\mathrm{AT}_{2}$ (Griendling et al. 1996, Unger et al. 1996, Fabiani 1999). In rodents, but not higher species or humans, two further isoforms of the $\mathrm{AT}_{1}$ receptor have been identified and termed $\mathrm{AT}_{1 \mathrm{a}}$ and $\mathrm{AT}_{1 \mathrm{~b}}$ (Iwai \& Inagami 1992, Yoshida et al. 1992). The characterisation of Ang II receptors into two major classes was promulgated by the development of selective non-peptide antagonists such as losartan and PD123319 (Timmermans et al. 1993). Ang II receptors sensitive to losartan were designated $\mathrm{AT}_{1}$, whereas those sensitive to PD123319 were designated $\mathrm{AT}_{2}$ (Timmermans et al. 1993). Ang II exerts a variety of biological effects that serve to modulate cardiovascular function and structure, including vasoconstriction, stimulation of aldosterone release and promotion of cell growth/ hypertrophy, all of which are mediated by the $\mathrm{AT}_{1}$ receptor (Chung et al. 1998, Fabiani 1999). The functional role of the $\mathrm{AT}_{2}$ receptor is less well understood, but may be involved in anti-proliferation, apoptosis, differentiation and, possibly, vasodilatation (Chung et al. 1998, Csikos et al. 1998, Fabiani 1999).

Of particular note, the RAS can interact with the sympathetic nervous system in a stimulatory manner at several different levels of the neuronal network (Saxena 1992). Ang II is well known to facilitate the release of NA from sympathetic nerve terminals in many tissues including the heart, kidney and blood vessels (Story \& Ziogas 1987). Moreover, Ang II is able to amplify the postjunctional actions of NA and other excitatory mediators on cardiac and smooth muscle cells (Purdy \& Weber 1988). This facilitatory effect on sympathetic transmission represents one of the most potent actions of Ang II, usually requiring concentrations that are much lower than those required to produce direct vasoconstriction or cardiac inotropic and chronotropic effects (Story \& Ziogas 1987).

Despite the known role of sympathetic activity in $\mathrm{BPH}$, as described above, the functional role of the RAS in the prostate is unknown. Furthermore, although it was reported several years ago that the biochemical activity of ACE is significantly greater in BPH than in normal prostate or a variety of other tissue homogenates
(Yokoyama et al. 1980, Van Sande et al. 1985), no further work has since been undertaken to investigate the physiological or pathophysiological role of the RAS in the prostate. Our group has shown more recently that both the protein and mRNA expression of ACE (Nassis et al. 2000, 2001), in addition to Ang II immunoreactivity (Dinh et al. 2001a), are increased in BPH. Furthermore, we have observed that $\mathrm{AT}_{1}$ receptors predominate in the human prostate and are down-regulated in BPH (Dinh et al. $2001 a, b)$. Taken together, these findings suggest that the local RAS is activated in BPH, which may have pathophysiological consequences.

Nothing is known about the functional interaction of the RAS with sympathetic nerves in the prostate. We hypothesise that a local tissue-based RAS is functionally active and facilitates sympathetic neuroeffector transmission in the prostate, such that hyperactivity of the local RAS contributes to the development of BPH by enhancing local sympathetic activity. In view of the possibility that the RAS may be activated in $\mathrm{BPH}$, the present study was undertaken to determine whether Ang II, the main effector molecule of the RAS, facilitates sympathetic transmission in the prostate. Specifically, we aimed to examine the effects of exogenous and locally generated Ang II on NA release from sympathetic nerves of the rat prostate and endeavoured to characterise the Ang II receptor subtype(s) involved.

\section{Materials and Methods}

\section{Rat prostate preparation}

Male Sprague-Dawley rats (250-350 g) were killed by decapitation and then exsanguinated. An incision was made in the lower abdominal region and the prostate identified and dissected free. The isolated prostate was transferred to a Petri dish containing pre-warmed physiological salt solution (PSS) and continuously gassed with carbogen $\left(95 \% \mathrm{O}_{2}-5 \% \mathrm{CO}_{2}\right)$. Excess fatty tissue was removed and the prostate cut into two even sections. Each piece of prostate tissue was tied at both ends with fine silk threads.

\section{Radiolabelling of noradrenergic transmitter stores with $\left.{ }^{3} \mathrm{H}\right] \mathrm{NA}$}

The procedure used to radiolabel the noradrenergic transmitter stores was adopted from Fabiani \& Story (1994, 1996). Prostate tissues were placed in small glass-jacketed organ baths and equilibrated for $10 \mathrm{~min}$ in $2 \mathrm{ml}$ PSS, maintained at $37^{\circ} \mathrm{C}$ and continuously gassed with carbogen. After this initial equilibration period, $5 \mu \mathrm{l}\left[{ }^{3} \mathrm{H}\right] \mathrm{NA}$ (30-50 Ci/mmol) was added to each organ bath and the preparations allowed to incubate for $30 \mathrm{~min}$. After incubation, prostate tissues were removed from the organ baths and immersed in a small volume of PSS to rinse any loosely bound radioactivity. Prostate preparations were then 
mounted vertically between two platinum electrodes in acrylic flow chambers and superfused with PSS at a rate of $2 \mathrm{ml} / \mathrm{min}$ using an ISCO Wiz peristaltic pump (ISCO Inc., Lincoln, NE, USA). In order to further remove loosely bound radioactivity, the tissues were washed for 90 min before experimental procedures were commenced. After the first $30 \mathrm{~min}$ of the washout period, the preparations were subjected to a $30 \mathrm{~s}$ period of electrical field stimulation with a train of $1 \mathrm{~ms}$ monophasic square-wave pulses at a frequency of $5 \mathrm{~Hz}$ and a supramaximal voltage of $20 \mathrm{~V}$, delivered by a Grass S88 stimulator (Grass Medical Instruments, Quincy, MA, USA). This brief 'priming stimulus' was intended to assist in the removal of any non-specifically bound radioactive material.

\section{Stimulation of intrinsic sympathetic nerves}

After the washout period, the intrinsic sympathetic nerves of the prostate preparations were subjected to two $60 \mathrm{~s}$ periods of electrical field stimulation $(1 \mathrm{~ms}$ pulses, $5 \mathrm{~Hz}$, $20 \mathrm{~V})$. The first period of stimulation was given immediately after the $90 \mathrm{~min}$ washout period and the second period of stimulation given $30 \mathrm{~min}$ later.

The effects of Ang II, Ang I and various drugs on the resting and stimulation-induced effluxes of radioactivity were examined by adding the drugs to the PSS superfusing the prostate preparations $15 \mathrm{~min}$ before the second period of stimulation. The drugs then remained present for the duration of the experiment.

\section{Determination of resting and stimulation-induced effluxes of radioactivity}

The superfusate from the prostate preparations was collected at 3 min intervals by an automated ISCO Retriever IV fraction collector (ISCO Inc.). Each $3 \mathrm{~min}$ (6 ml) fraction of superfusate was mixed with $4 \mathrm{ml}$ of scintillant (Ultima Gold, Packard Bioscience BV, Groningen, The Netherlands) and the radioactivity present determined by liquid scintillation counting. External automatic standardisation was utilised to correct for counting efficiency and the data were expressed in disintegrations per minute (d.p.m.).

The resting efflux of radioactivity from the prostate preparations was determined for each of the two periods of stimulation $\left(\mathrm{R}_{1}\right.$ and $\left.\mathrm{R}_{2}\right)$ from the amount of radioactivity present in the fraction of superfusate collected immediately before stimulation. The stimulation-induced efflux of radioactivity for each of the two periods of stimulation $\left(\mathrm{S}_{1}\right.$ and $\mathrm{S}_{2}$ ) was determined by subtracting the resting efflux from the amount of radioactivity present in each of the fractions of superfusate collected from the commencement of stimulation, and summing the differences:

$$
\begin{aligned}
& \mathrm{S}_{1}=\left(\mathrm{F}_{1}+\mathrm{F}_{2}+\mathrm{F}_{3} \ldots\right)-n \mathrm{R}_{1} \\
& \mathrm{~S}_{2}=\left(\mathrm{F}_{1}{ }^{\prime}+\mathrm{F}_{2}{ }^{\prime}+\mathrm{F}_{3}{ }^{\prime} \ldots\right)-n \mathrm{R}_{2}
\end{aligned}
$$

where $\mathrm{F}$ and $\mathrm{F}^{\prime}$ represent the radioactive content in each fraction collected after the first and second period of stimulation respectively, $\mathrm{R}_{1}$ and $\mathrm{R}_{2}$ represent the resting efflux for the first and second period of stimulation respectively and $n$ represents the number of fractions. In each experiment, the resting and stimulation-induced effluxes for the second period of stimulation were expressed as percentages of the corresponding values for the first period of stimulation $\left(\% \mathrm{R}_{2} / \mathrm{R}_{1}\right.$ and $\% \mathrm{~S}_{2} / \mathrm{S}_{1}$ respectively).

\section{Receptor constructs, expression and binding assay}

The cloning of the rat $\mathrm{AT}_{1 \mathrm{a}}$ receptor and its incorporation into the mammalian expression vector, $\mathrm{pRc} / \mathrm{CMV}$, have been described previously (Thekkumkara et al. 1995). The rat $\mathrm{AT}_{1 \mathrm{~b}}$ receptor, sub-cloned into $\mathrm{pRc} / \mathrm{CMV}$, was kindly provided by Dr $\mathrm{T} J$ Thekkumkara (Department of Medicine, University of Colorado, Denver, CO, USA). The rat $\mathrm{AT}_{2}$ cDNA was kindly provided by $\mathrm{Dr} \mathrm{T} J$ Murphy (Department of Pharmacology, Emory University School of Medicine, Atlanta, GA, USA) and subsequently sub-cloned into pRc/CMV using unique 5' (HindIII) and $3^{\prime}$ (XbaI) restriction sites.

Chinese hamster ovary (CHO-K1) cells were transfected in 12-well plates with $0.6 \mu \mathrm{g} /$ well of either $\mathrm{AT}_{1 \mathrm{a}}$, $\mathrm{AT}_{1 \mathrm{~b}}$ or $\mathrm{AT}_{2}$ receptor plasmid DNA using lipofectAMINE $(4 \cdot 8 \mu \mathrm{l} / \mathrm{well})$, as previously described (Thomas et al. 1998). At $48 \mathrm{~h}$ post-transfection, competition radioreceptor-binding assays were performed using $0 \cdot 05 \mathrm{nM}\left[{ }^{125} \mathrm{I}\right]$-Ang II as tracer and increasing concentrations of Ang II, losartan (an $\mathrm{AT}_{1}$-selective ligand), PD123319 (an $\mathrm{AT}_{2}$-selective ligand) or CGP42112 (an $\mathrm{AT}_{2}$-selective ligand). Non-linear regression of the data was achieved using GraphPad Prism (Graphpad Software Inc., San Diego, CA, USA) and $K_{\mathrm{D}}$ and $B_{\max }$ were determined by the method of Swillens (1992).

\section{Drugs, solutions and radiochemicals}

The following drugs were used: angiotensin II (AUSPEP Pty Ltd, Parkville, VIC, Australia; Sigma Chemical Co., St Louis, MO, USA); angiotensin I (AUSPEP Pty Ltd; Sigma Chemical Co.); $\omega$-conotoxin GVIA (AUSPEP Pty Ltd); tetrodotoxin (Sigma Chemical Co.); losartan (Merck \& Co. Inc., Rathway, NJ, USA), PD123319 (Research Biochemicals International, Natick, MA, USA), captopril (Sigma Chemical Co.), indomethacin (Sigma Chemical Co.), CGP42112 (Novartis Pharma AG, Basel, Switzerland), idazoxan (Research Biochemicals International), atropine (Sigma Chemical Co.), bradykinin (Sigma Chemical Co.) and Hoe140 (Hoechst AG, Frankfurt, Germany).

Stock solutions of indomethacin were made in $2 \mathrm{M}$ $\mathrm{Na}_{2} \mathrm{CO}_{3}$. All other stock solutions and intermediate dilutions of drugs were made in distilled water. Final concentrations of drugs were achieved by the appropriate 


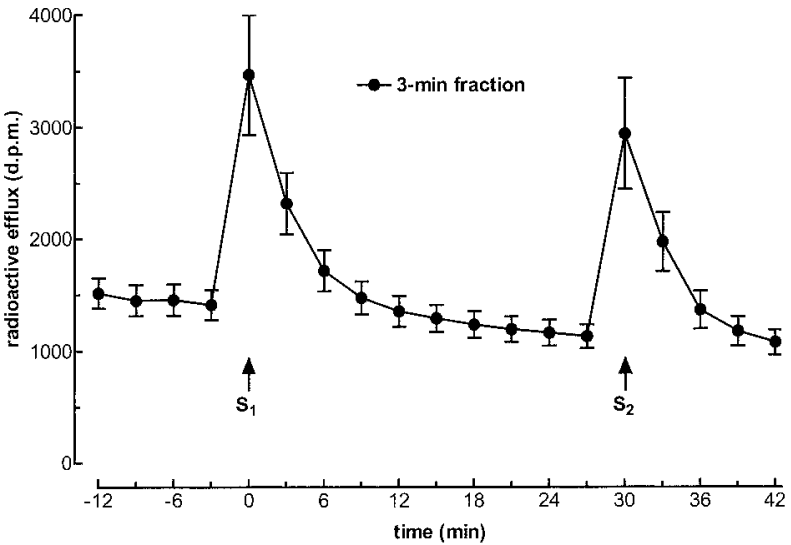

Figure 1 Effects of successive periods of electrical field stimulation on the radioactive efflux from isolated preparations of the rat prostate in which the noradrenergic transmitter stores had been loaded with $\left.{ }^{3} \mathrm{H}\right] \mathrm{NA}$. The intrinsic sympathetic nerves of the prostate were subjected to two $60 \mathrm{~s}$ periods of electrical field stimulation $\left(\mathrm{S}_{1}\right.$ and $\left.\mathrm{S}_{2}\right)$ at $5 \mathrm{~Hz}$, given 30 min apart. The graph shows the radioactive content, expressed in disintegrations per minute (d.p.m.), from consecutive 3-min fractions of superfusate collected against time (min). Each point on the graph represents the mean \pm S.E.M. of six prostate preparations.

dilution in PSS, continuously gassed with carbogen and maintained at a temperature of $37^{\circ} \mathrm{C}$.

The PSS had the following composition $(\mathrm{mM}): \mathrm{NaCl}$, 118; $\mathrm{KCl}, 4 \cdot 7 ; \mathrm{CaCl}_{2}, 2 \cdot 5 ; \mathrm{MgSO}_{4}, 0 \cdot 45 ; \mathrm{NaHCO}_{3}, 25$; $\mathrm{KH}_{2} \mathrm{PO}_{4}, \quad 1 \cdot 03$ and $\mathrm{D}-(+)$-glucose, 11.1. EDTA $(0.067 \mathrm{mM})$ and ascorbic acid $(0.14 \mathrm{mM})$ were also present to prevent oxidation of NA.

(L)-[Ring 7, 8- $\left.{ }^{3} \mathrm{H}\right]$-noradrenaline (specific activity 30-50 Ci/mmol) was supplied by Amersham Pharmacia Biotech Pty Ltd (Buckinghamshire, England, UK).

\section{Statistical analysis of results}

Results are expressed as meants.E.M.; $n$ represents the number of experiments. The levels of statistical significance of differences were determined by one-way analysis of variance (ANOVA) followed by Dunnett's test or Student-Newman-Keuls (SNK) test, where appropriate. All statistical analyses were performed using the statistical program SigmaStat for Windows (Jandel Scientific Software Inc., San Rafael, CA, USA). In all cases, probability levels less than $0.05 \quad(P<0 \cdot 05)$ were taken to indicate statistical significance.

\section{Results}

Effects of exogenous and locally-generated Ang II on $\left.{ }^{3} \mathrm{H}\right] \mathrm{NA}$ release from rat prostate

Control experiments Figure 1 shows the mean content of radioactivity (d.p.m.) in consecutive $3 \mathrm{~min}$ fractions of superfusate collected from control rat prostates $(n=6)$ loaded with $\left[{ }^{3} \mathrm{H}\right] \mathrm{NA}$ and subjected to two periods of stimulation. The mean resting efflux of radioactivity for the first period of electrical field stimulation $\left(\mathrm{R}_{1}\right)$ was $1414 \pm 134$ d.p.m. per 3 min collection $(n=6)$. There was a gradual decrease in the resting efflux between the two periods of stimulation, such that the resting efflux preceding the second period of stimulation, expressed as a percentage of the first $\left(\% \mathrm{R}_{2} / \mathrm{R}_{1}\right)$, had a mean value of $80 \cdot 1 \pm 1 \cdot 0 \%$. Electrical field stimulation evoked an increase in the radioactive efflux from prostate preparations loaded with $\left[{ }^{3} \mathrm{H}\right] \mathrm{NA}$. The mean stimulation-induced efflux evoked by the first period of stimulation $\left(S_{1}\right)$ was $2954 \pm 587$ d.p.m. $(n=6)$. The mean value of the stimulation-induced efflux for the second period of stimulation, expressed as a percentage of the first $\left(\% \mathrm{~S}_{2} / \mathrm{S}_{1}\right)$, was $87 \cdot 0 \pm 3 \cdot 0 \%$.

Characterisation of stimulation-induced efflux To confirm that the source of radioactivity released from the radiolabelled prostate by electrical field stimulation was due to the neuronal exocytotic release of $\left[{ }^{3} \mathrm{H}\right] \mathrm{NA}$ from sympathetic nerves, the effects of tetrodotoxin (neuronal $\mathrm{Na}^{+}$channel blocker), $\omega$-conotoxin (neuronal N-type $\mathrm{Ca}^{2+}$ channel blocker) and $\mathrm{Ca}^{2+}$-free PSS on stimulation-induced efflux were investigated. Tetrodotoxin $(1 \mu \mathrm{M}), \omega$-conotoxin $(0 \cdot 1 \mu \mathrm{M})$ and the removal of extracellular $\mathrm{Ca}^{2+}$ from the PSS, introduced $15 \mathrm{~min}$ before the second period of stimulation, virtually abolished the stimulation-induced efflux of radioactivity (Fig. $2 ; \quad P<0 \cdot 05)$. The selective $\alpha_{2}$-adrenoceptor antagonist idazoxan was used to determine whether transmitter NA release was subject to auto-inhibition mediated by prejunctional $\alpha_{2}$-adrenoceptors. Idazoxan $(0 \cdot 1 \mu \mathrm{M})$, introduced into the PSS $15 \mathrm{~min}$ before the second period of stimulation, markedly enhanced stimulation-induced efflux, by approximately 170\% above control (Fig. 2; $P<0 \cdot 05$ ).

Effects of Ang II and Ang I As shown in Fig. 3, introduction of exogenous Ang II $(0 \cdot 001-1 \mu \mathrm{M})$ into the PSS, $15 \mathrm{~min}$ before the second period of stimulation, produced a concentration-dependent increase in the stimulation-induced efflux of $\left[{ }^{3} \mathrm{H}\right] \mathrm{NA}$, with a maximal effect at $0 \cdot 1 \mu \mathrm{M}(P<0 \cdot 05)$. The precursor molecule Ang I was used to determine whether locally generated Ang II could also modulate transmitter NA release in the prostate. Similar to Ang II, Ang I $(0 \cdot 001-1 \mu \mathrm{M})$, introduced $15 \mathrm{~min}$ before the second period of stimulation, also enhanced the stimulation-induced efflux in a concentration-dependent manner, but was approximately 10 -fold less potent than Ang II, with a maximal effect at $1 \mu \mathrm{M}$ (Fig. 3; $P<0 \cdot 05$ ). The maximal increase in stimulation-induced efflux produced by both Ang II and Ang I was approximately $40 \%$ above control. 




Figure 2 Effects of various neuronal drugs and the removal of extracellular $\mathrm{Ca}^{2+}$ on the stimulation-induced (S-I) release of $\left[{ }^{3} \mathrm{H}\right] \mathrm{NA}$ from the rat prostate. The intrinsic sympathetic nerves of the prostate were subjected to two $60 \mathrm{~s}$ periods of electrical field stimulation at $5 \mathrm{~Hz}$, given 30 min apart. Where indicated, tetrodotoxin (TTX, $1 \mu \mathrm{M})$, $\omega$-conotoxin $(\omega$-CTX, $0 \cdot 1 \mu \mathrm{M})$ or idazoxan (IDZ, $0 \cdot 1 \mu \mathrm{M}$ ) was added to the PSS superfusing the prostate preparations, or the PSS was replaced with $\mathrm{Ca}^{2+}$-free PSS, $15 \mathrm{~min}$ before the second period of stimulation and then remained present throughout. The stimulation-induced efflux for the second period of stimulation was expressed as a percentage of the value for the first period $\left(\% S_{2} / S_{1}\right)$. Each column represents the mean \pm S.E.M. of four to six prostate preparations. ${ }^{*}$ Significant difference from control $(P<0 \cdot 05$, ANOVA, Dunnett's test $)$.

Effects of Ang II and Ang I in the presence of losartan The Ang II receptor antagonists losartan, PD123319 and CGP4112 were used to characterise the angiotensin receptor subtype(s) mediating the effects of Ang II and Ang I on stimulation-induced $\left.{ }^{3} \mathrm{H}\right] \mathrm{NA}$ release. When introduced alone $15 \mathrm{~min}$ before the second period of stimulation, the $\mathrm{AT}_{1}$ receptor antagonist losartan had no effect on stimulation-induced efflux. However, when introduced $15 \mathrm{~min}$ before the second period of stimulation in combination with Ang II $(0 \cdot 1 \mu \mathrm{M})$ or Ang I $(1 \mu \mathrm{M})$, losartan $(0 \cdot 01$ and $0 \cdot 1 \mu \mathrm{M})$ significantly inhibited the increase in stimulation-induced efflux produced by Ang II and Ang I, in a concentration-dependent manner (Fig. 4; $P<0 \cdot 05)$.

Effects of Ang II and Ang I in the presence of PD123319 When introduced alone $15 \mathrm{~min}$ before the second period of stimulation, the $\mathrm{AT}_{2}$ receptor antagonist PD123319 had no effect on the stimulation-induced efflux. However, as seen with losartan, when introduced in combination with Ang II $(0 \cdot 1 \mu \mathrm{M})$ or Ang I $(1 \mu \mathrm{M})$ 15 min before the second period of stimulation, PD123319 $(0 \cdot 01$ and $0 \cdot 1 \mu \mathrm{M})$ also inhibited the increase in

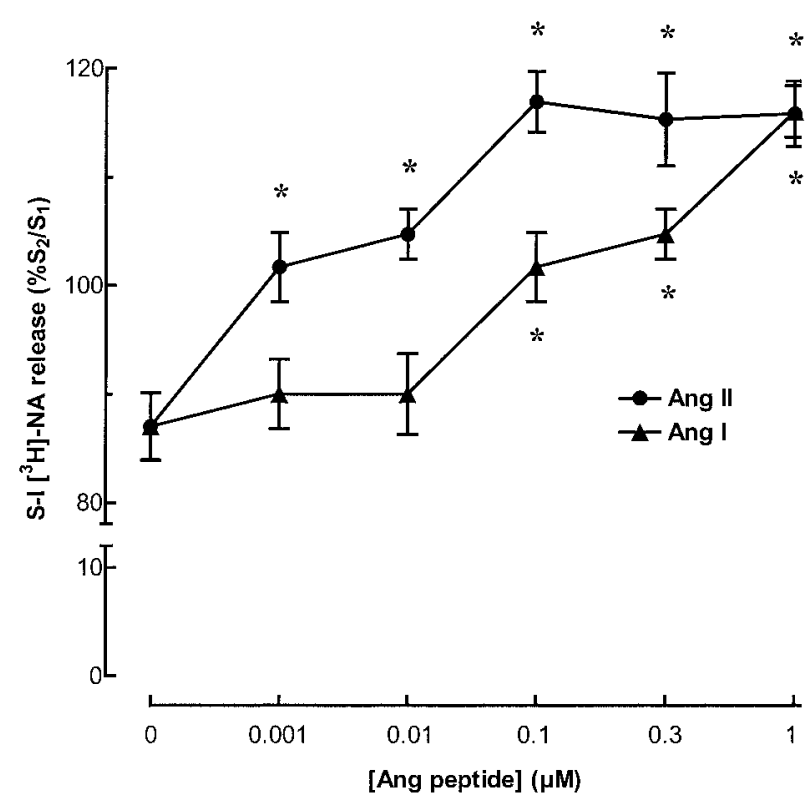

Figure 3 Effects of Ang II and Ang I on the stimulation-induced (S-I) release of $\left[{ }^{3} \mathrm{H}\right] \mathrm{NA}$ from the rat prostate. The intrinsic sympathetic nerves of the prostate were subjected to two $60 \mathrm{~s}$ periods of electrical field stimulation at $5 \mathrm{~Hz}$, given 30 min apart. Ang II or Ang I (0.001-1 $\mu \mathrm{M})$ was added to the PSS superfusing the prostate preparations $15 \mathrm{~min}$ before the second period of stimulation and then remained present throughout. The stimulation-induced efflux for the second period of stimulation was expressed as a percentage of the value for the first period $\left(\% \mathrm{~S}_{2} / \mathrm{S}_{1}\right)$. Each point on the graph represents the mean \pm S.E.M. of four to nine prostate preparations. *Significant difference from control (0) $(P<0 \cdot 05$, ANOVA, Dunnett's test).

stimulation-induced efflux produced by Ang II and Ang I, in a concentration-dependent manner (Fig. 5; $P<0 \cdot 05$ ).

Effects of Ang II and Ang I in the presence of CGP42112 When introduced alone $15 \mathrm{~min}$ before the second period of stimulation, the $\mathrm{AT}_{2}$ receptor ligand CGP42112, like PD123319 or losartan, had no effect on the stimulation-induced efflux. However, in contrast to PD123319 or losartan, CGP42112 $(0 \cdot 01$ and $0 \cdot 1 \mu \mathrm{M})$, introduced in combination with Ang II $(0 \cdot 1 \mu \mathrm{M})$ or Ang I $(1 \mu \mathrm{M})$, did not alter the facilitatory effect of Ang II or Ang I on stimulation-induced efflux (Fig. 6; $P>0 \cdot 05$ ).

Effects of Ang I in the presence of captopril The ACE inhibitor captopril was used to determine whether the effects of Ang I on stimulation-induced efflux were due to generation of Ang II via an ACE-dependent pathway. When introduced alone $15 \mathrm{~min}$ before the second period of stimulation, captopril $(3 \mu \mathrm{M})$ produced a small but significant increase in stimulation-induced efflux (Fig. 7; $P<0 \cdot 05)$. However, when introduced in combination with Ang I $(1 \mu \mathrm{M}) 15 \mathrm{~min}$ before the second period 


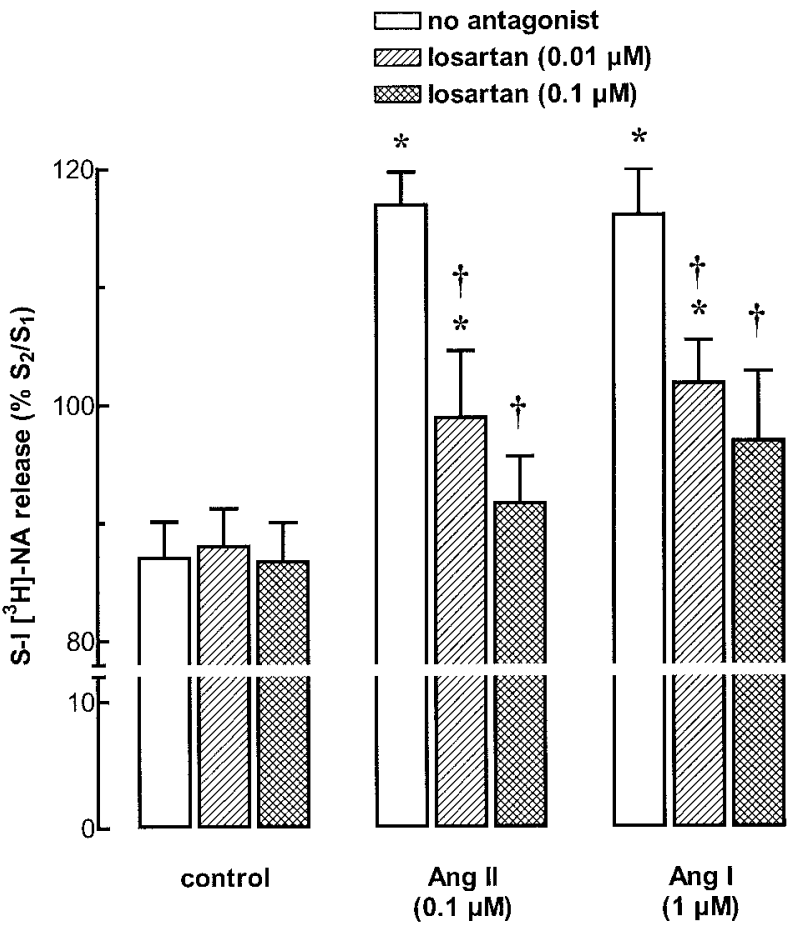

Figure 4 Effects of Ang II and Ang I in the absence and presence of losartan on the stimulation-induced $(\mathrm{S}-\mathrm{I})$ release of $\left[{ }^{3} \mathrm{H}\right] \mathrm{NA}$ from the rat prostate. The intrinsic sympathetic nerves of the prostate were subjected to two $60 \mathrm{~s}$ periods of electrical field stimulation at $5 \mathrm{~Hz}$, given $30 \mathrm{~min}$ apart. Ang II $(0 \cdot 1 \mu \mathrm{M})$, Ang I $(1 \mu \mathrm{M})$ or losartan $(0 \cdot 01$ and $0 \cdot 1 \mu \mathrm{M})$ was added to the PSS superfusing the prostate preparations $15 \mathrm{~min}$ before the second period of stimulation and then remained present throughout. The stimulation-induced efflux for the second period of stimulation was expressed as a percentage of the value for the first period $\left(\% \mathrm{~S}_{2} / \mathrm{S}_{1}\right)$. Each column represents the mean \pm S.E.M. of four to six prostate preparations. * Significant difference from corresponding control $(P<0 \cdot 05$, ANOVA, Dunnett's test); †significant effect of losartan $(P<0 \cdot 05$, ANOVA, SNK test).

of stimulation, captopril $(3 \mu \mathrm{M})$ markedly inhibited the facilitation of stimulation-induced efflux by Ang I (Fig. 7; $P<0 \cdot 05)$.

Effects of bradykinin in the absence and presence of Hoe140 or captopril The potential effects of bradykinin on transmitter NA release in the prostate were also investigated. Bradykinin $(1 \mu \mathrm{M})$, introduced $15 \mathrm{~min}$ before the second period of stimulation, produced a significant increase in the stimulation-induced efflux, approximately $35 \%$ above control (Fig. $7 ; P<0 \cdot 05$ ). The selective $B_{2}$ receptor antagonist Hoe140 was used to characterise the bradykinin receptor subtype involved in mediating the effects of bradykinin on stimulationinduced efflux. When introduced alone $15 \mathrm{~min}$ before the second period of stimulation, Hoe140 had no effect on the stimulation-induced efflux. However, when introduced in



Figure 5 Effects of Ang II and Ang I in the absence and presence of PD123319 on the stimulation-induced $(S-I)$ release of $\left[{ }^{3} \mathrm{H}\right] \mathrm{NA}$ from the rat prostate. The intrinsic sympathetic nerves of the prostate were subjected to two $60 \mathrm{~s}$ periods of electrical field stimulation at $5 \mathrm{~Hz}$, given 30 min apart. Ang II $(0 \cdot 1 \mu \mathrm{M})$, Ang I $(1 \mu \mathrm{M})$ or PD123319 $(0 \cdot 01$ and $0 \cdot 1 \mu \mathrm{M})$ was added to the PSS superfusing the prostate preparations $15 \mathrm{~min}$ before the second period of stimulation and then remained present throughout. The stimulation-induced efflux for the second period of stimulation was expressed as a percentage of the value for the first period $\left(\% \mathrm{~S}_{2} / \mathrm{S}_{1}\right)$. Each column represents the mean \pm S.E.M. of four to six prostate preparations. ${ }^{*}$ Significant difference from corresponding control $(P<0.05$, ANOVA, Dunnett's test); †significant effect of PD123319 ( $P<0 \cdot 05$, ANOVA, SNK test).

combination with bradykinin $(1 \mu \mathrm{M}) 15$ min before the second period of stimulation, Hoe140 $(0 \cdot 3$ and $1 \mu \mathrm{M})$ significantly inhibited the facilitatory effect of bradykinin $(1 \mu \mathrm{M})$ on the stimulation-induced efflux (Fig. 7; $P<0 \cdot 05)$.

The ACE inhibitor captopril was used again to determine whether exogenously applied bradykinin is subject to degradation by ACE in the prostate. As shown in Fig. 7 , in the presence of captopril $(3 \mu \mathrm{M})$, introduced $15 \mathrm{~min}$ before the second period of stimulation, bradykinin further increased the stimulation-induced efflux, to approximately $50 \%$ above control and about $15 \%$ greater than that achieved with bradykinin alone $(P<0 \cdot 05)$. Interestingly, when introduced in combination with captopril $(3 \mathrm{mM})$ $15 \mathrm{~min}$ before the second period of stimulation, Hoe140 $(1 \mu \mathrm{M})$ inhibited the increase in stimulation-induced efflux produced by captopril $(3 \mu \mathrm{M})$ alone (Fig. 7 ; $P<0 \cdot 05)$. 






control



Ang II
$(0.1 \mu \mathrm{M})$

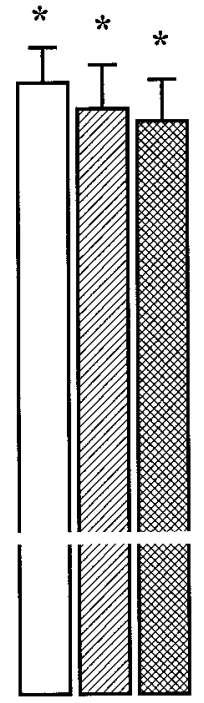

Ang I

Figure 6 Effects of Ang II and Ang I in the absence and presence of CGP42112 on the stimulation-induced (S-I) release of $\left[{ }^{3} \mathrm{H}\right] \mathrm{NA}$ from the rat prostate. The intrinsic sympathetic nerves of the prostate were subjected to two $60 \mathrm{~s}$ periods of electrical field stimulation at $5 \mathrm{~Hz}$, given 30 min apart. Ang II $(0 \cdot 1 \mu \mathrm{M})$, Ang I $(1 \mathrm{mM})$ or CGP42112 $(0.01$ and $0.1 \mu \mathrm{M})$ was added to the PSS superfusing the prostate preparations $15 \mathrm{~min}$ before the second period of stimulation and then remained present throughout. The stimulation-induced efflux for the second period of stimulation was expressed as a percentage of the value for the first period $\left(\mathrm{S}_{2} / \mathrm{S}_{1}\right)$. Each column represents the mean \pm S.E.M. of four to six prostate preparations. *Significant difference from corresponding control $(P<0 \cdot 05$, ANOVA, Dunnett's test).

Effects of drugs on resting effluxes Addition of all the various drugs tested had little or no effect on the mean values of resting efflux $\left(\% \mathrm{R}_{2} / \mathrm{R}_{1}\right)$ (data not shown).

Competition displacement of $\left[{ }^{125} I\right]$-Ang II binding from the cloned rat $A T_{1 a}, A T_{1 b}$ or $A T_{2}$ receptor in CHO-K1 cells

In order to characterise further the receptor subtype mediating the effects of Ang II on NA release, binding studies were also performed in $\mathrm{CHO}$ cells expressing each of the cloned rat $\mathrm{AT}_{1 \mathrm{a}}, \mathrm{AT}_{1 \mathrm{~b}}$ and $\mathrm{AT}_{2}$ receptor. Figure 8 shows competition displacement curves of $\left[{ }^{125} \mathrm{I}\right]$-Ang II binding to the cloned rat $\mathrm{AT}_{1 \mathrm{a}}, \mathrm{AT}_{1 \mathrm{~b}}$ and $\mathrm{AT}_{2}$ receptor expressed in $\mathrm{CHO}-\mathrm{K} 1$ cells (three experiments performed in triplicate). The $\mathrm{AT}_{1 \text { a }}$ receptor displayed a $K_{\mathrm{D}}$ of $1 \cdot 8 \pm 0 \cdot 3 \mathrm{nM}$ for Ang II and a receptor density $\left(B_{\max }\right)$ of $1066 \pm 356 \mathrm{fmol} / \mathrm{mg}$ protein. The $K_{\mathrm{D}}$ and $B_{\max }$ for the $\mathrm{AT}_{1 \mathrm{~b}}$ receptor were $4 \cdot 9 \pm 1 \cdot 4$ and $571 \pm 160 \mathrm{fmol} / \mathrm{mg}$ protein respectively, whereas those for the $\mathrm{AT}_{2}$ receptor were

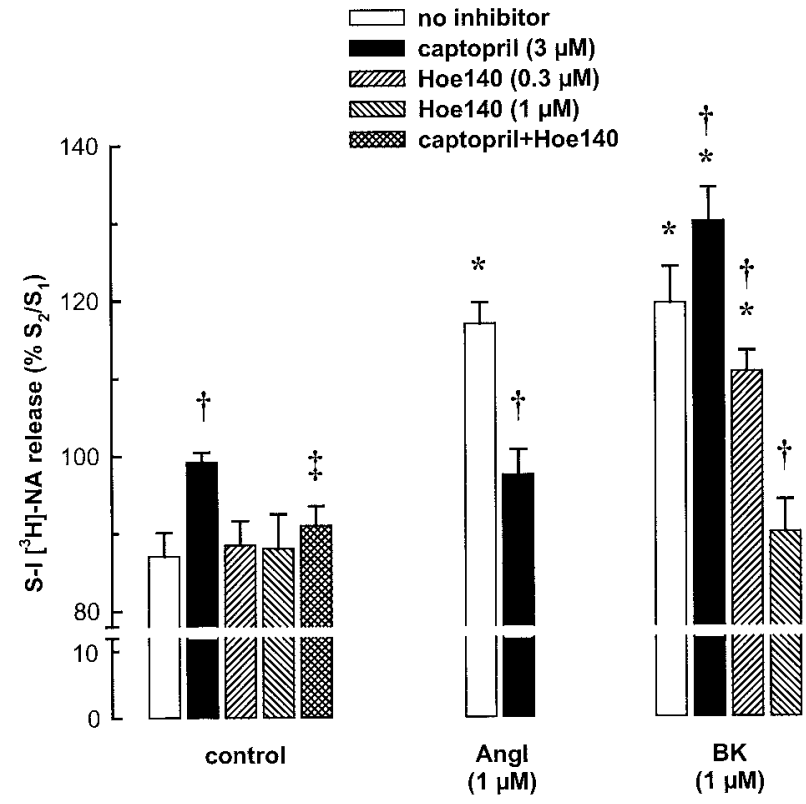

Figure 7 Effects of Ang I and bradykinin (BK) in the absence and presence of captopril or Hoe140 on the stimulation-induced (S-I) release of $\left[{ }^{3} \mathrm{H}\right] \mathrm{NA}$ from the rat prostate. The intrinsic sympathetic nerves of the prostate were subjected to two $60 \mathrm{~s}$ periods of electrical field stimulation at $5 \mathrm{~Hz}$, given 30 min apart. Ang I $(1 \mu \mathrm{M})$, bradykinin $(1 \mu \mathrm{M})$, captopril $(3 \mu \mathrm{M})$ or Hoe140 $(0 \cdot 3$ and $1 \mu \mathrm{M}$ ) was added to the PSS superfusing the prostate preparations $15 \mathrm{~min}$ before the second period of stimulation and then remained present throughout. The stimulation-induced efflux for the second period of stimulation was expressed as a percentage of the value for the first period $\left(\% \mathrm{~S}_{2} / \mathrm{S}_{1}\right)$. Each column represents the mean \pm S.E.M. of four to six prostate preparations. * Significant difference from corresponding control $(P<0 \cdot 05$, ANOVA, Dunnett's test); †significant effect of captopril or HOE140 $(P<0 \cdot 05$, ANOVA, SNK test); $\ddagger$ significant difference between captopril plus Hoe140 and captopril alone $(P<0 \cdot 05$, ANOVA, SNK test).

$3 \cdot 3 \pm 0 \cdot 7 \mathrm{nM}$ and $1254 \pm 301 \mathrm{fmol} / \mathrm{mg}$ protein. Displacement of $\left[{ }^{125} \mathrm{I}\right]$-Ang II by losartan was observed for the $\mathrm{AT}_{1 \mathrm{a}}$ and $\mathrm{AT}_{1 \mathrm{~b}}$ receptors, but not the $\mathrm{AT}_{2}$ receptor, whereas PD123319 and CGP 42112 displaced bound $\left[{ }^{125} \mathrm{I}\right]$-Ang II from the $\mathrm{AT}_{2}$ receptor, but not the $\mathrm{AT}_{1 \mathrm{a}}$ or $\mathrm{AT}_{1 \mathrm{~b}}$ receptor.

\section{Discussion}

Recent evidence from our laboratory suggests that the local RAS is activated in BPH. It is well documented that Ang II, the bioactive product of the RAS, facilitates sympathetic transmission in many cardiovascular organs by enhancing the release of the chemical transmitter NA from sympathetic nerve terminals. However, nothing is known about the interaction of the RAS with sympathetic neurotransmission in the prostate, which may possibly be implicated in the pathophysiology of $\mathrm{BPH}$. Therefore, the 

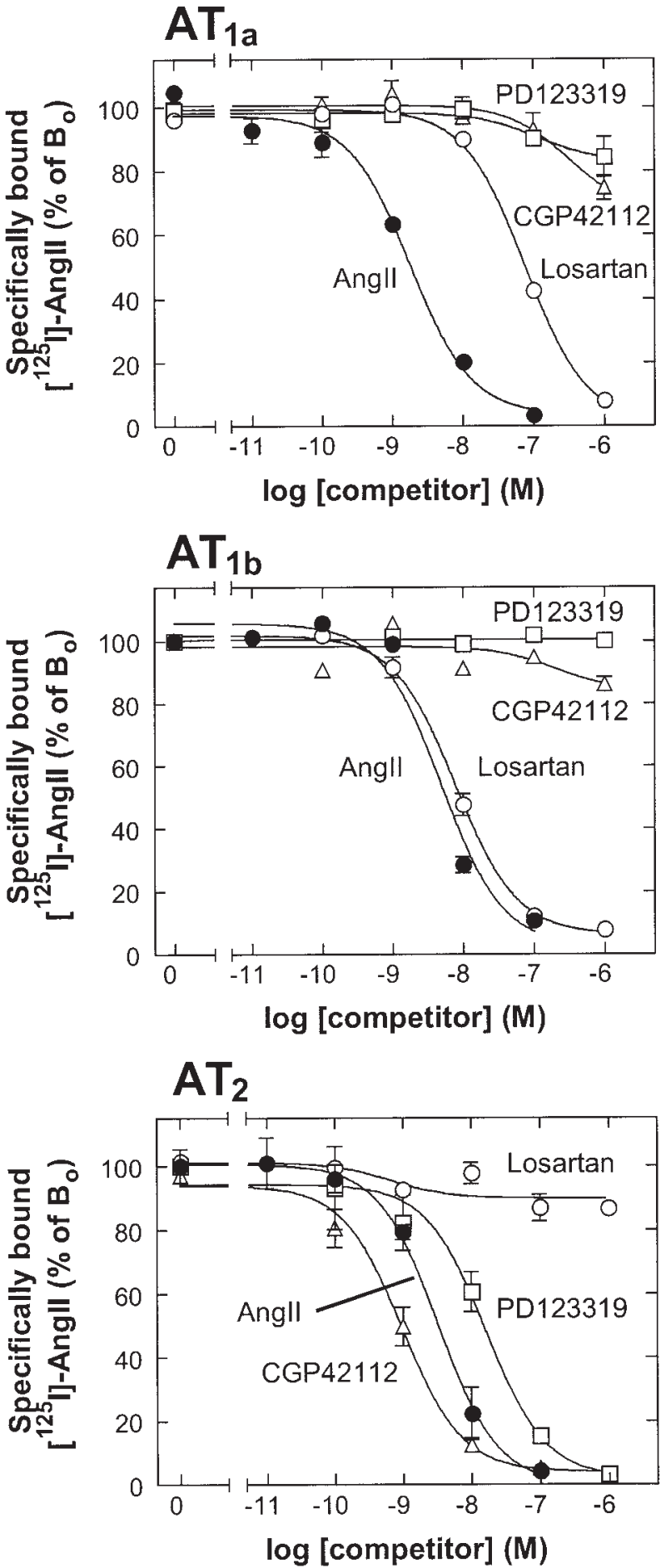

Figure 8 Competition displacement of specific $\left[{ }^{125} \mathrm{I}\right]-\mathrm{Ang}$ II binding by unlabelled Ang II, losartan, PD123319 and CGP42112 $\left(1 \times 10^{-11}-1 \times 10^{-6} \mathrm{M}\right)$ in $\mathrm{CHO}-\mathrm{K} 1$ cells expressing the cloned rat $\mathrm{AT}_{1 \mathrm{a}}, \mathrm{AT}_{1 \mathrm{~b}}$ or $\mathrm{AT}_{2}$ receptor. Data are expressed as a percentage of initial specific binding $\left(\mathrm{B}_{\mathrm{o}}\right)$ in the absence of any drugs $\left(\%\right.$ of $\left.B_{o}\right)$. Each point represents the mean \pm S.E.M. of three experiments performed in triplicate. present study was undertaken to determine whether exogenous and locally generated Ang II enhances transmitter NA release in the rat prostate, in an effort to ascribe a functional role of the local RAS in modulating sympathetic activity in the prostate.

Radiotracer techniques have been used widely and extensively to monitor transmitter NA release in many sympathetically innervated tissues. The noradrenergic transmitter stores of the rat prostate were labelled with $\left[{ }^{3} \mathrm{H}\right] \mathrm{NA}$, as described previously (Fabiani \& Story 1994, 1996). Electrical field stimulation evoked an increase in the efflux of radioactivity from the radiolabelled prostate preparations. The neuronal $\mathrm{Na}^{+}$channel blocker tetrodotoxin, the neuronal $\mathrm{N}$-type $\mathrm{Ca}^{2+}$ channel blocker $\omega$-conotoxin, and the removal of extracellular $\mathrm{Ca}^{2+}$ each abolished the stimulation-induced efflux of radioactivity. This confirms that the stimulation-induced efflux is caused by the neuronal exocytotic release of $\left[{ }^{3} \mathrm{H}\right] \mathrm{NA}$ by a mechanism dependent on the influx of $\mathrm{Ca}^{2+}$ through $\mathrm{N}$-type $\mathrm{Ca}^{2+}$ channels. It is well established that sympathetic nerve terminals are endowed with $\alpha_{2}$-adrenoceptors that subserve auto-inhibition of transmitter NA release (Starke 1987, Rand et al. 1990, Fuder \& Muscholl 1996). In the present study, the $\alpha_{2}$-adrenoceptor antagonist idazoxan markedly enhanced stimulation-induced $\left[{ }^{3} \mathrm{H}\right] \mathrm{NA}$ release in the rat prostate, which is consistent with blockade of prejunctional inhibitory $\alpha_{2^{-}}$ adrenoceptors on sympathetic nerve terminals, and similar to that observed in other tissues, such as rat atria (Loiacono et al. 1985, Story et al. 1985), human atria (Abadie et al. 1996), rat kidney (Rump et al. 1990), rat mesenteric artery (Fabiani \& Story 1996) and rabbit ear artery (Loiacono et al. 1985). These initial findings suggest that the stimulation-induced efflux from the radiolabelled rat prostate is caused by the evoked exocytotic release of $\left[{ }^{3} \mathrm{H}\right] \mathrm{NA}$ from sympathetic nerves and is subject to auto-inhibition mediated by prejunctional $\alpha_{2}$-adrenoceptors. Thus the stimulation-induced efflux may be taken as an index of transmitter NA release from sympathetic nerves of the rat prostate.

It is generally accepted that one of the most important actions of Ang II on sympathetic neurotransmission is the prejunctional facilitation of transmitter NA release (Story \& Ziogas 1987, Saxena 1992). In the present study, Ang II, over a concentration range of $0 \cdot 001-1 \mu \mathrm{M}$, enhanced the stimulation-induced efflux of $\left[{ }^{3} \mathrm{H}\right] \mathrm{NA}$ in a concentration-dependent manner, with a maximal effect at $0.1 \mu \mathrm{M}$, of approximately $35 \%$ above control. The facilitatory effect of Ang II on stimulation-induced $\left[{ }^{3} \mathrm{H}\right] \mathrm{NA}$ release in the rat prostate is consistent with findings in other tissues such as the rat caudal artery (Cox et al. 1995, 1996a,b), rat and human kidney (Rump et al. 1990, 1995), guinea-pig (Brasch et al. 1993) and human atria (Rump et al. 1994, Abadie et al. 1996).

Many tissues, including blood vessels, heart, kidney, adrenals and brain, are capable of generating Ang II locally 
(Campbell 1987, Dzau 1988, Johnston 1992). In the present study, the precursor molecule Ang I was therefore used to determine whether locally generated Ang II could modulate transmitter NA release in the prostate. Similar to Ang II, the inactive precursor Ang I also enhanced the $\left.{ }^{3} \mathrm{H}\right] \mathrm{NA}$ release in a concentration-dependent fashion but was approximately 10-fold less potent than Ang II. The facilitatory effect of Ang I on $\left[{ }^{3} \mathrm{H}\right] \mathrm{NA}$ release in the rat prostate was markedly inhibited by the ACE inhibitor captopril, indicating that the effects of Ang I are due to local conversion to Ang II via an ACE-dependent pathway. This finding suggests that a tissue-based RAS is indeed present and functionally active in the rat prostate and capable of generating Ang II locally. Facilitation of $\left.{ }^{3} \mathrm{H}\right] \mathrm{NA}$ release by Ang I in the rat prostate is consistent with other studies in guinea-pig atria (Ziogas et al. 1984, Brasch et al. 1993), rat kidney (Böke \& Malik 1983, Rump et al. 1990), human kidney (Rump et al. 1995), and rat vena cava (Ziogas \& Story 1991), which was reportedly caused by locally generated Ang II.

We also endeavoured to characterise the Ang II receptor subtype(s) mediating the actions of Ang II on sympathetic transmission in the rat prostate. Previous studies suggest that, in a number of tissues from different species such as guinea-pig atria (Brasch et al. 1993), rat atria (Gironacci et al. 1994), human atria (Rump et al. 1994), rat trachea (Boicos et al. 1996), human kidney (Rump et al. 1995) and various mouse tissues (Cox et al. 1999), the facilitatory effect of Ang II on transmitter NA release is mediated by $\mathrm{AT}_{1}$ receptors, as they were inhibited by losartan and unaffected by PD123319. However, in the present study, the increase in $\left[{ }^{3} \mathrm{H}\right] \mathrm{NA}$ release by both Ang II and Ang I in the rat prostate was significantly inhibited, in a concentration-dependent manner, by the selective $\mathrm{AT}_{1}$ receptor antagonist losartan in addition to the $\mathrm{AT}_{2}$ receptor antagonist $\mathrm{PD}$ 123319, whereas the other $\mathrm{AT}_{2}$ receptor antagonist, CGP42112, had no effect. These findings suggest that the receptor mediating the effects of exogenous and locally generated Ang II on NA release in the rat prostate involves a receptor that is sensitive to both losartan and PD123319. Similar findings have also been reported by Cox et al. $(1995,1996 a, b)$ who showed that the facilitation of $\left[{ }^{3} \mathrm{H}\right] \mathrm{NA}$ release by Ang II in the rat caudal artery was also inhibited by both losartan and PD123319.

The other $\mathrm{AT}_{2}$ receptor antagonist, CGP42112, did not alter the facilitatory effect of Ang II and Ang I on $\left.{ }^{3} \mathrm{H}\right] \mathrm{NA}$ release, which suggests that $A_{2}$ receptors may not be involved. Cloning studies have revealed the existence of at least two subtypes of the $\mathrm{AT}_{1}$ receptor in rodents (rats and mice), but not higher species or humans, which have been designated $\mathrm{AT}_{1 \mathrm{a}}$ and $\mathrm{AT}_{1 \mathrm{~b}}$ (Iwai \& Inagami 1992, Yoshida et al. 1992). Interestingly, it has been reported in rat mesangial cells that two distinct $\mathrm{AT}_{1}$ receptor binding sites exist, which are coupled to activation of phospholipase $\mathrm{C}$-mediated intracellular $\mathrm{Ca}^{2+}$ mobilisation and inhibition of adenylate cyclase, and sensitive to inhibition by losartan and PD123319 but not CGP42112 (Ernsberger et al. 1992, Zhou et al. 1993, Madhun et al. 1993). The $\mathrm{AT}_{1}$ binding site that displayed a greater affinity for losartan was denoted $\mathrm{AT}_{1 \mathrm{~A}}$, and the other binding site, which displayed a greater affinity for PD123319, was denoted $\mathrm{AT}_{1 \mathrm{~B}}$ (here, subscript A and B denote the pharmacologically characterised receptors, as opposed to the cloned receptors denoted by subscript $a$ and $b$ ).

To delineate further the Ang II receptor subtype involved in mediating the effects of Ang II on transmitter NA release in the rat prostate, Ang II binding studies were performed in $\mathrm{CHO}$ cells expressing each of the cloned rat Ang II receptors $\left(\mathrm{AT}_{1 \mathrm{a}}, \mathrm{AT}_{1 \mathrm{~b}}\right.$ and $\left.\mathrm{AT}_{2}\right)$ to establish their sensitivity to inhibition by losartan, PD123319 and CGP42112. As expected, losartan inhibited Ang II binding in a concentration-dependent manner in $\mathrm{CHO}$ cells transfected with either the $\mathrm{AT}_{1 \mathrm{a}}$ or $\mathrm{AT}_{1 \mathrm{~b}}$ receptor, whereas PD123319 and CGP42112 had little or no effect. Conversely, PD123319 and CGP42112 inhibited Ang II binding in $\mathrm{CHO}$ cells expressing the $\mathrm{AT}_{2}$ receptor and losartan had little or no effect. As the functional receptor mediating the effects of Ang II on NA release in the rat prostate was sensitive to inhibition by both losartan and PD123319 but not CGP42112, this receptor subtype does not appear to correspond to the cloned $\mathrm{AT}_{1 \mathrm{a}}, \mathrm{AT}_{1 \mathrm{~b}}$ or $\mathrm{AT}_{2}$ as determined by binding studies in $\mathrm{CHO}$ cells. We therefore propose that the functional receptor mediating the effects of Ang II on sympathetic transmission in the rat prostate may be similar to the functional $\mathrm{AT}_{1 \mathrm{~B}}$ receptor as described above (Ernsberger et al. 1992, Zhou et al. 1993, Madhun et al. 1993, Cox et al. 1995, 1996a,b), which is pharmacologically distinct from the cloned rat $\mathrm{AT}_{1 \mathrm{~b}}$ receptor.

We have observed in other studies the overwhelming presence of typical $\mathrm{AT}_{1}$ receptors in both the human (Dinh et al. 2001a,b) and rat prostate (unpublished observations). Given that several isoforms of the $\mathrm{AT}_{1}$ receptor exist in the rat but not in the human, coupled with the apparent absence of $\mathrm{AT}_{2}$ receptors in the rat prostate, the functional AT receptor mediating the effects of Ang II on NA release in the rat prostate would appear to represent a novel subtype of the $\mathrm{AT}_{1}$ receptor that is uniquely sensitive to both losartan and PD123319 but not to CGP42112. This novel prejunctional AT receptor mediating the effects of Ang II on NA release in the rat prostate represents only a fraction of the total AT receptor pool in the rat prostate. Furthermore, given that the human prostate expresses almost exclusively $\mathrm{AT}_{1}$ receptors but not $\mathrm{AT}_{2}$ receptors, and that humans are not known to express any isoforms of the $\mathrm{AT}_{1}$ receptor, it seems highly likely that the potential effects of Ang II on NA release in the human prostate would also be mediated by the $\mathrm{AT}_{1}$ receptor, which is still consistent with the findings in the rat prostate. Thus the characterisation of this functional $\mathrm{AT}_{1 \mathrm{~B}}$ receptor subtype mediating the effects of Ang II 
on NA release in the rat prostate represents a unique phenomenon in the rat and might not be pertinent in the human prostate, as humans are not known to contain any isoforms of the $\mathrm{AT}_{1}$ receptor. Unfortunately, because of the unavailability of fresh and functionally viable human prostate tissues, it is not possible also to conduct NA release studies in the human prostate in order to compare directly the effects of Ang II on NA release in the rat prostate, and the receptor subtype involved, with that in the human prostate. Nonetheless, the findings of the present study provide direct evidence that Ang II facilitates NA release in the rat prostate, which may have direct implications for the pathophysiology of $\mathrm{BPH}$ in humans (see below).

Very recently, it was reported that $\mathrm{AT}_{1}$ and bradykinin $\mathrm{B}_{2}$ receptors form stable heterodimers in vascular smooth muscle cells and that this association dramatically affects the signalling and regulation of the $\mathrm{AT}_{1}$ receptor (AbdAlla et al. 2000). Whether $\mathrm{AT}_{1}$ and $\mathrm{B}_{2}$ receptors dimerise and cross-modulate in the prostate remains to be determined, but such a possibility may also be responsible for the changes in $\mathrm{AT}_{1}$ receptor pharmacology and functionality observed.

ACE has broad substrate specificity which, in addition to converting Ang I to Ang II, also degrades bradykinin to inactive peptide fragments (Fabiani et al. 2000). In the present study, captopril itself produced a significant increase in $\left.{ }^{3} \mathrm{H}\right] \mathrm{NA}$ release. The facilitatory effect of captopril on transmitter NA release in the rat prostate may potentially be the result of accumulation of bradykinin as a consequence of impaired bradykinin degradation after ACE inhibition. Indeed, the observed increase in $\left[{ }^{3} \mathrm{H}\right] \mathrm{NA}$ release in the rat prostate was inhibited by the bradykinin $\mathrm{B}_{2}$ antagonist Hoe140, suggesting that this facilitatory effect of captopril was mediated by bradykinin. Bradykinin has been shown to enhance transmitter NA release in a variety of tissues, including rat kidney (Böke \& Malik 1983) and human kidney (Rump et al. 1995), rat and mouse vas deferens (Llona et al. 1991), rat atria (Chulak et al. 1995) and human atria (Rump et al. 1997), and rat hypothalamus (Tsuda et al. 1993). Consistent with these observations, bradykinin enhanced $\left[{ }^{3} \mathrm{H}\right] \mathrm{NA}$ release in the rat prostate to an extent similar to that produced by Ang II or Ang I, suggesting that bradykinin enhances sympathetic transmission in the prostate. Moreover, the effect of bradykinin on $\left[{ }^{3} \mathrm{H}\right]$ NA release was further enhanced after ACE inhibition with captopril, suggesting that exogenous bradykinin is subject to degradation by prostatic ACE. This is consistent with the findings of other studies in which the facilitatory effect of bradykinin on NA release was revealed after ACE inhibition with captopril in the human kidney and atria (Rump et al. 1995, 1997). These effects of bradykinin on $\left[{ }^{3} \mathrm{H}\right] \mathrm{NA}$ release in the rat prostate were significantly inhibited by Hoe140, suggesting that facilitation of transmitter NA release by bradykinin in the rat prostate is mediated by $B_{2}$ receptors. This is also in accordance with other studies in which bradykinin was found to increase NA release in the rat heart (Kurz et al. 1997) and mouse heart (Chulak et al. 1998), pithed rat and PC12 cells (Dendorfer \& Dominiak 1995, Dendorfer et al. 1996) via $B_{2}$ receptors - an effect that was markedly antagonised by Hoe140.

These findings suggest that ACE may have an important neuromodulatory role on sympathetic transmission in the prostate by regulating the synthesis of Ang II and the metabolism of bradykinin, both of which have demonstrable effects on transmitter NA release in the rat prostate. Therefore, although ACE inhibition may suppress local Ang II-mediated effects on sympathetic transmission in the prostate, this may potentially be compensated by the effects mediated by bradykinin accumulation. Further to this, bradykinin has been shown to induce contraction of the canine prostate, which can be potentiated further by ACE inhibition (Steidle et al. 1990). Thus, if the RAS has an obligatory role in the pathophysiology of BPH, then suppression of the RAS with $\mathrm{AT}_{1}$ receptor blockers, rather than ACE inhibition, may offer potential benefits by virtue of the fact that the former do not interfere with bradykinin metabolism.

The findings of the present study provide direct evidence that Ang II enhances NA release from sympathetic nerves of the rat prostate. These data establish a novel functional role for the RAS in the modulation of sympathetic transmission in the prostate, which may have important implications for the understanding of the pathophysiology of BPH. Increased local sympathetic activity is a characteristic feature of $\mathrm{BPH}$ and represents a target for drug treatment with $\alpha_{1}$-adrenoceptor blockers. Recent findings from our laboratory suggest that the local RAS is activated in BPH. Specifically, we have shown that the expression of ACE mRNA and protein (Nassis et al. 2000, 2001) and Ang II peptide (Dinh et al. 2001a) is significantly increased in $\mathrm{BPH}$ compared with the normal prostate. Furthermore, we have demonstrated that $\mathrm{AT}_{1}$ receptors predominate in the human prostate and are down-regulated in $\mathrm{BPH}$, which may be due to receptor internalisation as a result of receptor hyper-stimulation by increased tissue concentrations of Ang II (Dinh et al. $2001 a, b)$. It is possible, therefore, that hyperactivity of the local RAS resulting in increased tissue concentrations of Ang II may represent an important factor in the pathophysiology of BPH by enhancing local sympathetic activity in the prostate. Facilitation of NA release from sympathetic nerves by Ang II would consequently result in hyper-stimulation of $\alpha_{1}$-adrenoceptors, causing contraction of prostatic smooth muscle and urethral compression, with subsequent resistance to urinary outflow.

In conclusion, exogenous and locally generated Ang II facilitates the release of NA from sympathetic nerves of the rat prostate by a prejunctional mechanism. The receptor subtype mediating the effects of Ang II on sympathetic transmission in the rat prostate is unclear, but may involve 
a novel functional Ang II receptor distinct from the cloned $\mathrm{AT}_{1 \mathrm{a}}, \mathrm{AT}_{1 \mathrm{~b}}$ or $\mathrm{AT}_{2}$. These novel data provide direct evidence in support of a functional role for the local RAS in modulating sympathetic activity in the prostate, which may have important implications for the pathophysiology of $\mathrm{BPH}$.

\section{Acknowledgements}

We gratefully acknowledge the financial support of the National Health \& Medical Research Council of Australia, Commonwealth Department of Veteran's Affairs, Sir Edward Dunlop Medical Research Foundation, Clive \& Vera Ramaciotti Medical Research Foundation and Austin Hospital Medical Research Foundation.

\section{References}

Abadie C, Foucart S, Page P \& Nadeau R 1996 Modulation of noradrenaline release from isolated human atrial appendages. Journal of the Autonomic Nervous System 61 269-276.

AbdAlla S, Lother H \& Quitterer U $2000 \mathrm{AT}_{1}$-receptor heterodimers show enhanced G-protein activation and altered receptor sequestration. Nature 407 94-98.

Boicos K, Cox SL, Fabiani ME \& Story DF 1996 AT $_{1}$ receptors subserve enhancement of noradrenergic transmission by angiotensin II in the rat trachea. Proceedings of the Australasian Society of Clinical and Experimental Pharmacologists and Toxicologists 3112.

Böke T \& Malik KU 1983 Enhancement by locally generated angiotensin II of release of the adrenergic transmitter in the isolated rat kidney. Journal of Pharmacology and Experimental Therapeutics 226 900-907.

Brasch H, Sieroslawski L \& Dominiak P 1993 Angiotensin II increases norepinephrine release from atria by acting on angiotensin subtype 1 receptors. Hypertension 22 699-704.

Campbell DJ 1987 Circulating and tissue angiotensin systems. Journal of Clinical Investigation 79 1-6.

Chulak C, Couture R \& Foucart S 1995 Modulatory effect of bradykinin on the release of noradrenaline from rat isolated atria. British Journal of Pharmacology 115 330-334.

Chulak C, Couture R \& Foucart S 1998 Modulatory effect of bradykinin on noradrenaline release in isolated atria from normal and $\mathrm{B}_{2}$ knockout transgenic mice. European Journal of Pharmacology $346167-174$.

Chung O, Kuhl H, Stoll M \& Unger T 1998 Physiological and pharmacological implications of $\mathrm{AT}_{1}$ versus $\mathrm{AT}_{2}$ receptors. Kidney International 67 (Suppl) S95-S99.

Cox SL, Ben A, Story DF \& Ziogas J 1995 Evidence for the involvement of different receptor subtypes in the pre- and postjunctional actions of angiotensin II at rat sympathetic neuroeffector sites. British Journal of Pharmacology 114 1057-1063.

Cox SL, Story DF \& Ziogas J 1996a Multiple prejunctional actions of angiotensin II on noradrenergic transmission in the caudal artery of the rat. British Journal of Pharmacology 119 976-984.

Cox SL, Story DF \& Ziogas J 1996 b Angiotensin II receptors involved in the enhancement of noradrenergic transmission in the caudal artery of the spontaneously hypertensive rat. British Journal of Pharmacology 119 965-975.

Cox SL, Trendelenburg AU \& Starke K 1999 Prejunctional angiotensin receptors involved in the facilitation of noradrenaline release in mouse tissues. British Journal of Pharmacology 127 1256-1262.
Csikos T, Chung O \& Unger T 1998 Receptors and their classification: focus on angiotensin II and the $\mathrm{AT}_{2}$ receptor. Journal of Human Hypertension 12 311-318.

Dendorfer A \& Dominiak P 1995 Characterization of bradykinin receptors mediating catecholamine release in PC12 cells. Naunyn Schmiedebergs Archives of Pharmacology 351 274-281.

Dendorfer A, Hauser W, Falias D \& Dominiak P 1996 Bradykinin increases catecholamine release via $\mathrm{B}_{2}$ receptors. Pflugers Archives 432 (Suppl 3) R99-R106.

Dinh DT, Frauman AG, Somers GR, Ohishi M, Zhuo J, Casley DJ, Johnston CI \& Fabiani ME 2001a Evidence for activation of the renin-angiotensin system in the human prostate: increased angiotensin II and reduced $\mathrm{AT}_{1}$ receptor expression in benign prostatic hyperplasia. Journal of Pathology (In Press).

Dinh DT, Frauman AG, Sourial M, Casley DJ, Johnston CI \& Fabiani ME $2001 b$ Identification, distribution and expression of angiotensin II receptors in the normal human prostate and benign prostatic hyperplasia. Endocrinology 142 1349-1356.

Dzau VJ 1988 Circulating versus local renin-angiotensin system in cardiovascular homeostasis. Circulation 7 I4-I3.

Ernsberger P, Zhou J, Damon TH \& Douglas JG 1992 Angiotensin II receptor subtypes in cultured rat renal mesangial cells. American Journal of Physiology 263 F411-F416.

Fabiani ME 1999 Angiotensin receptor subtypes: novel targets for cardiovascular therapy. Drug News and Perspectives 12 207-215.

Fabiani ME \& Story DF 1994 Prejunctional effects of cromakalim, nicorandil and pinacidil on noradrenergic transmission in rat isolated mesenteric artery. Journal of Autonomic Pharmacology 14 87-98.

Fabiani ME \& Story DF 1996 Inhibition of sympathetic noradrenergic transmission by guanabenz and guanethidine in rat isolated mesenteric artery: involvement of neuronal potassium channels. Pharmacological Research 33 171-180.

Fabiani ME, Dinh DT, Nassis L \& Johnston CI 2000 Angiotensinconverting enzyme: basic properties, distribution, and functional role. In Hypertension: A Companion to Brenner and Rector's The Kidney, ch 9, pp 90-100. Eds S Oparil \& MA Weber. Philadelphia: WB Saunders Co.

Forray C, Bard JA, Wetzel JM, Chiu G, Shapiro E, Tang R, Lepor H, Hartig PR, Weinshank RL, Branchek TA \& Gluchowski C 1994 The $\alpha_{1}$-adrenergic receptor that mediates smooth muscle contraction in human prostate has the pharmacological properties of the cloned human $\alpha_{1 c}$-subtype. Molecular Pharmacology 45 703-708.

Fuder H \& Muscholl E 1996 Heteroreceptor-mediated modulation of noradrenaline and acetylcholine release from peripheral nerves. Reviews of Physiology Biochemistry and Pharmacology 12 327-380.

Furuya S, Kumamoto Y, Yokoyama E, Tsukamoto T, Izumi T \& Abiko Y 1982 Alpha-adrenergic activity and urethral pressure in prostatic zone in benign prostatic hypertrophy. Journal of Urology 128 836-839.

Garraway WM, Collins GN \& Lee RJ 1991 High prevalence of benign prostatic hypertrophy in the community. Lancet 338 469-471.

Gironacci MM, Adler-Graschinsky E, Pena C \& Enero MA 1994 Effects of angiotensin II and angiotensin-(1-7) on the release of $\left[{ }^{3} \mathrm{H}\right]$ norepinephrine from rat atria. Hypertension 24 457-460.

Griendling KK, Lassegue B \& Alexander RW 1996 Angiotensin receptors and their therapeutic implications. Annual Review of Pharmacology and Toxicology 36 281-306.

Isaacs JT \& Coffey DS 1989 Etiology and disease process of benign prostatic hyperplasia. Prostate 2 (Suppl) 33-50.

Iwai N \& Inagami T 1992 Identification of two subtypes in the rat type I angiotensin II receptor. FEBS Letters 298 257-260.

Johnston CI 1990 Biochemistry and pharmacology of the reninangiotensin system. Drugs 39 (Suppl 1) 21-31.

Johnston CI 1992 Franz Volhard Lecture. Renin-angiotensin system: a dual tissue and hormonal system for cardiovascular control. Journal of Hypertension 10 (Suppl 7) S13-S26. 
Kirby RS 1989 Alpha-adrenoceptor inhibitors in the treatment of benign prostatic hyperplasia. American Journal of Medicine $\mathbf{8 7}$ (Suppl 2A): $26 \mathrm{~S}-30 \mathrm{~S}$

Kurz T, Tolg R \& Richardt G 1997 Bradykinin B 2 -receptormediated stimulation of exocytotic noradrenaline release from cardiac sympathetic neurons. Journal of Molecular and Cellular Cardiology $292561-2569$.

Loiacono RE, Rand MJ \& Story DF 1985 Interaction between the inhibitory action of acetylcholine and the alpha-adrenoceptor autoinhibitory feedback system on release of $\left[{ }^{3} \mathrm{H}\right]$-noradrenaline from rat atria and rabbit ear artery. British Journal of Pharmacology 84 697-705.

Llona I, Galleguillos X, Belmar J \& Huidobro-Toro JP 1991 Bradykinin modulates the release of noradrenaline from vas deferens nerve terminals. Life Sciences 48 2585-2592.

McNeal J 1990 Pathology of benign prostatic hyperplasia: insight into etiology. Urologic Clinics of North America 17 477-486.

McVary KT, Razzaq A, Lee C, Venegas MF, Rademaker A \& McKenna KE 1994 Growth of the rat prostate gland is facilitated by the autonomic nervous system. Biology of Reproduction $\mathbf{5 1}$ 99-107.

Madhun ZT, Ernsberger P, Ke FC, Zhou J, Hopfer U \& Douglas JG 1993 Signal transduction mediated by angiotensin II receptor subtypes expressed in rat renal mesangial cells. Regulatory Peptides $\mathbf{4 4}$ 149-157.

Madsen FA \& Bruskewitz RC 1995 Benign prostatic hyperplasia: pathophysiology and pharmacological treatment. Current Opinion in Nephrology and Hypertension 4 455-459.

Marshall I, Burt RP \& Chapple CR 1995 Noradrenaline contractions of human prostate mediated by $\alpha_{1 \mathrm{~A}}\left(\alpha_{1 \mathrm{c}}\right)$-adrenoceptor subtype British Journal of Pharmacology 115 781-786.

Maruenda J, Bhatnagar V \& Lowenthal DT 1999 Hypertension in the elderly with coexisting benign prostatic hyperplasia. Urology $\mathbf{5 3}$ (Suppl 3a) 7-12.

Nassis L, Frauman AG, Johnston CI \& Fabiani ME 2000 Localisation and expression of angiotensin-converting enzyme protein and mRNA in the human prostate. Journal of the American Society of Nephrology 11 425A-426A.

Nassis L, Frauman AG, Ohishi M, Zhuo J, Casley DJ, Johnston CI \& Fabiani ME 2001 Localisation of angiotensin-converting enzyme in the human prostate: Pathological expression in benign prostatic hyperplasia. Journal of Pathology (In Press).

Nicholls MG, Richards AM \& Agarwal M 1998 The importance of the renin-angiotensin system in cardiovascular disease. Journal of Human Hypertension 12 295-299.

Peach MJ 1977 Renin-angiotensin system: biochemistry and mechanisms of action. Physiological Reviews 57 313-370.

Purdy RE \& Weber MA 1988 Angiotensin II amplification of adrenergic vasoconstriction: role of receptor reserve. Circulation Research 63 748-757.

Rand MJ, Tung LH, Louis WJ \& Story DF 1986 Cardiac alphaadrenoceptors: postjunctional and prejunctional. Journal of Molecular and Cellular Cardiology 18 (Suppl 5) 17-32.

Rand MJ, Majewski H \& Story DF 1990 Modulation of neurotransmission. In Cardiovascular Pharmacology, pp 229-292. Ed. M Antonaccio. New York: Raven Press.

Rump LC, Schuster MJ, Wilde K \& Schollmeyer P 1990 Modulation of noradrenaline release from rat cortical kidney slices: effects of angiotensin I and II. British Journal of Clinical Pharmacology 30 (Suppl 1) $168 \mathrm{~S}-170 \mathrm{~S}$.

Rump LC, Schwertfeger E, Schaible U, Fraedrich G \& Schollmeyer P $1994 \beta_{2}$-Adrenergic receptor and angiotensin II receptor modulation of sympathetic neurotransmission in human atria. Circulation Research 74 434-440.

Rump LC, Bohmann C, Schaible U, Schultze-Seemann W \& Schollmeyer PJ 1995 B-Adrenergic, angiotensin II, and bradykinin receptors enhance neurotransmission in human kidney. Hypertension 26 445-451.
Rump LC, Berlit T, Schwertfeger E, Beyersdorf F, Schollmeyer P \& Bohmann C 1997 Angiotensin converting enzyme inhibition unmasks the sympathofacilitatory effect of bradykinin in human right atrium. Journal of Hypertension 15 1263-1270.

Saxena PR 1992 Interaction between the renin-angiotensinaldosterone and sympathetic nervous systems. Journal of Cardiovascular Pharmacology 19 (Suppl 6) S80-S88.

Starke K 1987 Presynaptic alpha-autoreceptors. Reviews of Physiology Biochemistry and Pharmacology 107 73-146.

Steidle CP, Cohen ML \& Neubauer BL 1990 Bradykinin-induced contractions of canine prostate and bladder: effect of angiotensin converting enzyme inhibition. Journal of Urology 144 390-392.

Story DF \& Ziogas J 1987 Interaction of angiotensin II with noradrenergic transmission. Trends in Pharmacological Sciences $\mathbf{8}$ 269-271.

Story DF, Standford-Starr CA \& Rand MJ 1985 Evidence for the involvement of $\alpha_{1}$-adrenoceptors in negative feedback regulation of noradrenergic transmitter release in rat atria. Clinical Science $\mathbf{6 8}$ (Suppl 10) 111S-115S.

Swillens S 1992 How to estimate the total receptor concentration when the specific radioactivity of the ligand is unknown. Trends in Pharmacological Sciences 13 430-434.

Thekkumkara TJ, Du J, Dostal DE, Motel TJ, Thomas WG \& Baker KM 1995 Stable expression of a functional rat angiotensin II $\left(\mathrm{AT}_{1 \mathrm{~A}}\right)$ receptor in $\mathrm{CHO}-\mathrm{K} 1$ cells: rapid desensitization by angiotensin II. Molecular and Cellular Biochemistry 146 79-89.

Thomas WG, Motel TJ, Kule CE, Karoor V \& Baker KM 1998 Phosphorylation of the angiotensin II $\left(\mathrm{AT}_{1 \mathrm{~A}}\right)$ receptor carboxyl terminus: a role in receptor endocytosis. Molecular Endocrinology 12 1513-1524.

Timmermans PB, Wong PC, Chiu AT, Herblin WF, Benfield P, Carini DJ, Lee RJ, Wexler RR, Saye JA \& Smith RD 1993 Angiotensin II receptors and angiotensin II receptor antagonists. Pharmacological Reviews 45 205-251.

Tsuda K, Tsuda S, Goldstein M, Nishio I \& Masuyama Y 1993 Effects of bradykinin on $\left[{ }^{3} \mathrm{H}\right]$-norepinephrine release in rat hypothalamus. Clinical and Experimental Pharmacology and Physiology 20 787-791.

Unger T, Chung O, Csikos T, Culman J, Gallinat S, Gohlke P, Hohle S, Meffert S, Stoll M, Stroth U \& Zhu YZ 1996 Angiotensin receptors. Journal of Hypertension 14 (Suppl 5) S95-S103.

Van Sande ME, Scharpé SL, Neels HM \& Van Camp KO 1985 Distribution of angiotensin converting enzyme in human tissues. Clinica Chimica Acta 147 255-260.

Yokoyama M, Hiwada K, Kokubu T, Takaha M \& Takeuchi M 1980 Angiotensin-converting enzyme in human prostate. Clinica Chimica Acta 100 253-258.

Yoshida H, Kakuchi J, Guo DF, Furuta H, Iwai N, van der Meer-de Jong R, Inagami T \& Ichikawa I1992 Analysis of the evolution of angiotensin II type 1 receptor gene in mammals (mouse, rat, bovine and human). Biochemical and Biophysical Research Communications 186 1042-1049.

Zhou J, Ernsberger P \& Douglas JG 1993 A novel angiotensin receptor subtype in rat mesangium. Coupling to adenylyl cyclase. Hypertension 21 1035-1038.

Ziogas J \& Story DF 1991 Angiotensin II generation in the rat vena cava: stimulation of local synthesis by beta-adrenoceptor activation. Naunyn Schmiedebergs Archives of Pharmacology 343 31-36.

Ziogas J, Story DF \& Rand MJ 1984 Effects of locally generated angiotensin II on noradrenergic transmission in guinea-pig isolated atria. European Journal of Pharmacology 106 11-18.

Received 23 February 2001

Accepted 5 July 2001 